\title{
INITIAL SCREENING OF FAST-GROWING TREE SPECIES BEING TOLERANT OF DRY TROPICAL PEATLANDS IN CENTRAL KALIMANTAN, INDONESIA
}

\author{
Hideyuki Saito ${ }^{1)}$, Masato Shibuya ${ }^{1)}$, Sehat Jaya Tuah $^{2)}$, Maman Turjaman ${ }^{3)}$, \\ Kunihide Takahashi ${ }^{1)}$, Yahya Jamal ${ }^{2)}$, Hendrik Segah ${ }^{2)}$, Patricia Erosa Putir ${ }^{2)}$, \\ and Suwido Hester Limin
}

\begin{abstract}
An investigation of the recruit, survivorship and growth of naturally regenerating tree species on canal bank was conducted to select tree species which are suitable for preceding planting in drained and burnt peat swamp lands in Central Kalimantan, Indonesia. Top of the canal bank were open, with greater soil moisture deficit and higher soil temperatures than on the next intact forest floor. The abundant trees were asam-asam (Ploiarium alternifolium), garunggang (Cratoxylon arborescens) and tumih (Combretocarpus rotundatus). New regeneration of these trees on the canal bank was confirmed during this investigation and mortality was very low. These results indicated that $P$. alternifolium, $C$. arborescens and $C$. rotundatus were tolerant of intensive radiation, soil drought and high soil temperatures during germination. The annual height increments were $189-232 \mathrm{~cm} \mathrm{y}^{-1}$ (P. alternifolium), $118-289 \mathrm{~cm} \mathrm{y}^{-1}(C$. arborescens) and $27-255 \mathrm{~cm} \mathrm{y}^{-1}$ (C. rotundatus); thus, these three species could be classified as fast-growing with tolerance to open and dry conditions. Such characteristics were important to avoid competition with herbs, ferns, and/or climbers. The results suggest that $P$. alternifolium, $C$. arborescens and C. rotundatus are suitable for preceding planting for the rehabilitation of the disturbed peat swamp forests of Central Kalimantan.
\end{abstract}

Keywords: fast-growing, rehabilitation, regeneration, survivorship

\section{INTRODUCTION}

Tropical peat swamp forests in Central Kalimantan, Indonesia, are one of the most threatened terrestrial ecosystems (Boehm and Siegert, 2001) providing timber and also functioning as global carbon storage and biodiversity reservoir (Jaya et al., 2001; Kobayashi 1988). Since 1979, the peat swamp forests have been drained by numerous canals between rivers for the development of agricultural land (Jaya et al., 2001). Further, agricultural activity, commercial logging, and frequent wildfires have disturbed the drained forests; and many burned forests and abandoned agricultural lands have been covered by herbs, ferns, and/or climbers without natural tree regeneration (Kobayashi, 1994, 2000). These disturbances degraded the chemical composition of peat soil, as making it nutrient-poor and acidic. These degraded soil conditions inhibited the regeneration of trees needed for an ecologically and

\footnotetext{
1) Graduate School of Agriculture, Hokkaido University

${ }^{2}$ CIMTROP, University of Palangkaraya, Palangkaraya

3) Forest and Nature Conservation Research and Development Center, Bogor
} 
commercially valuable forest (Kobayashi, 1994; Kobayashi et al., 1996). Therefore, it is necessary to accelerate rehabilitation following disturbance. However, in the tropical peat swamps of Central Kalimantan, no techniques of afforestation have been developed to date.

Commercially expensive and ecologically important tree species are generally valuable for afforestation. In this point of view, dipterocarps are among the candidate plants for afforestation. However, it may be difficult to plant these trees in open areas, because many dipterocarps require adequate shading during early growth (intolerant) and need to be planted underneath other trees to become established.

One technique for the afforestation of intolerant trees is the preceding planting method of site preparation (Sasaki and Asakawa, 1994). In this technique a canopy of fast-growing trees that tolerate open conditions is established prior to the planting of tolerant species. In Central Kalimantan, the ecological and physiological characteristics of trees, e.g., pioneer or late-successional, tolerant or intolerant, have not been classified. Thus, it is necessary to identify fast-growing tree species that can tolerate open and dry conditions. These species should be native to the area in order to avoid a disturbance in biodiversity (Sugandhy, 1997).

The aim of this study was to select several tree species which were suitable for preceding planting in an open and drained peatlands of Central Kalimantan. For immediate screening and without a large-scale experiment, it was focused on naturally regenerating tree species in an open area on a canal bank which was mound made of peat soil. The condition of this bank seemed providing opportunities for seedling establishment. There were sufficient nutrients available, but fairly stressful, based on the intensive radiation, drought and high soil temperatures found there. Also, there were similarities to those found in drained, burned and degraded peat swamp forest. It was possible that the trees regenerating on the canal bank could tolerate open and dry peatlands and that they had potential to be used for site preparation of preceding planting method. In this study, to confirm that the conditions of the canal bank were stressful, soil moisture and temperature were measured and compared to those of a forest. To aid the selection of some fast-growing tree species that were tolerant open and dry peatland conditions, the species that regenerated naturally on the canal bank were noted and the recruit, survivorship and height growth were investigated. The possibility of using the selected tree species for preceding planting is discussed on the basis of their ecological and commercial characteristics.

\section{MATERIALS AND METHODS}

The study site was located on the Kalampangan Canal in Palangkaraya, Central Kalimantan, Indonesia (220'S, 1142'E). The mean annual temperature recorded at a meteorological center in Palangkaraya Airport was $26-28^{\circ} \mathrm{C}$ between 1996 and 1999. The mean annual temperature and precipitation at this study site in 2002 were $26.7^{\circ} \mathrm{C}$ and $1856 \mathrm{~mm}$ respectively (Takashi Hirano, unpublished data). The warmth index was approximately 260 to 270 (Kira, 1977). In this area, approximately $4 \mathrm{~m}$ thickness of peat soil layer was accumulated.

The canal bank was $2 \mathrm{~m}$ height above ground level and $10 \mathrm{~m}$ wide at the top (Figure 1) and was dug from peat soil in 1995. Isolated trees, shrubs, herbs and ferns established on the canal bank in 2000. The vegetation on the canal bank seemed to be regenerated after the construction of the bank. Two $10 \times 50$-m plots were established on the Kalampangan Canal 
Bank in October 2000. One of the plots was set up on the top of the canal bank, called as plot $\mathrm{I}$, and another was set up at $1 \mathrm{~m}$ height above ground level, called as Plot II (Figure 1). All tree seedlings and saplings were tagged for identification in the both plots. In the plot I, height of trees including newly occurred trees were measured in October 2000, November 2001 and November 2002, in the beginning of the rainy season.

Soil temperature and soil moisture in the experimental plots as well as in a natural peat swamp forest near the plots were measured. Measurements were conducted around noon on a sunny day in October 2000 and November 2002. Soil temperature at a depth of $0.5 \mathrm{~cm}$ and 5 cm was measured with a thermometer (MF1000, Chino, Tokyo, Japan). The volumetric water content of the soil at a depth of $0-10 \mathrm{~cm}$ was measured with an FDR portable sensor (ML2x, Delta-T devices Ltd., Cambridge, UK).

The significance of differences in soil temperature and volumetric soil water content was examined using Scheffé's test. Statistical analysis was conducted using SPSS ver.12.0 (SPSS, Inc., Chicago, IL).

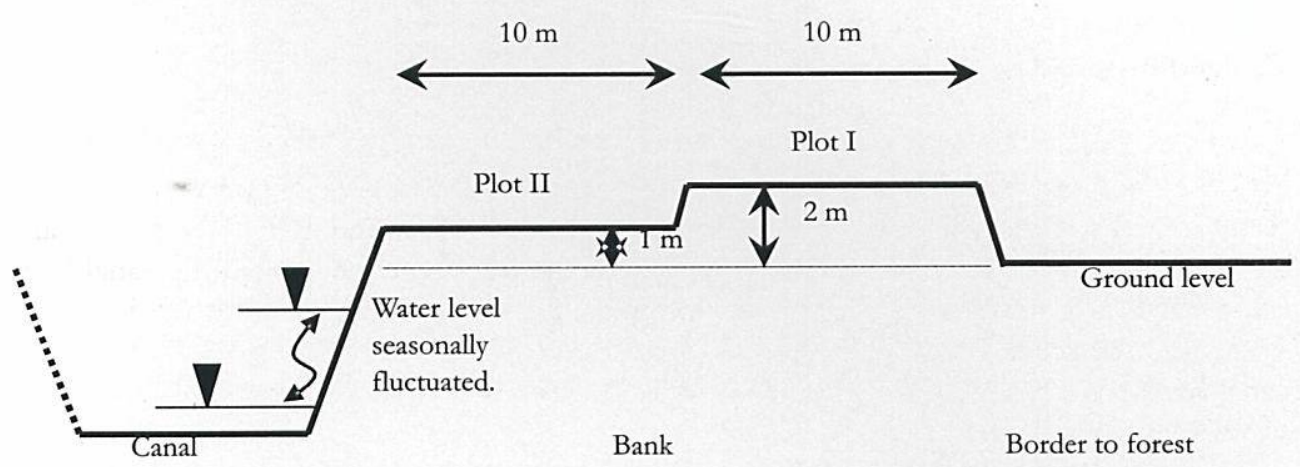

Figure 1. Scheme of canal bank cross section and plot location

\section{RESULTS AND DISCUSSIONS}

\section{A. Environmental Conditions}

The top of canal bank was exposed to intensive radiation in daytime. The soil temperature at the depth of $5 \mathrm{~cm}$ was $31.4 \pm 1.8^{\circ} \mathrm{C}$ in plot I and $31.0 \pm 1.2^{\circ} \mathrm{C}$ in Plot II at $10: 00$ am, as compared to $27.4 \pm 0.7^{\circ} \mathrm{C}$ on the forest floor of a natural forest (Scheffe, $p<0.001$, Table 1). At 14:00, soil temperature at the depth of $5 \mathrm{~cm}$ was $34.0 \pm 1.0^{\circ} \mathrm{C}$ in plot $\mathrm{I}$ and $33.8 \pm 1.5^{\circ} \mathrm{C}$ in Plot II, as compared to $30.1 \pm 0.8^{\circ} \mathrm{C}$ on the forest floor of the natural forest (Scheffe, $p<0.001$, Table 1). At a depth of $0.5 \mathrm{~cm}$, soil temperature on the canal bank reached up to $>60^{\circ} \mathrm{C}$ under sunny conditions during mid-day. The volumetric soil moisture content at a depth of $0-10 \mathrm{~cm}$ was $17.0 \pm 2.9 \%$ in Plot I and $17.6 \pm 3.0 \%$ in Plot II, whereas on the forest floor it was $33.2 \pm 2.6 \%$ (Scheffe, $p<0.001$, Table 1$)$. 
Table 1. Environmental condition in canal bank and forest floors

\begin{tabular}{|l|c|c|c|c|c|}
\hline \multirow{2}{*}{$\begin{array}{c}\text { Environmental } \\
\text { variable }\end{array}$} & \multirow{2}{*}{ Time } & \multirow{2}{*}{$\begin{array}{c}\text { Depth } \\
(\mathrm{cm})\end{array}$} & \multicolumn{2}{|c|}{ Canal Bank } & Forest \\
\cline { 4 - 5 } & & Plot I & Plot II & floor \\
\hline Soil moisture (\%) & $10: 00$ & $0-10$ & $17.0-2.9^{\mathrm{a}}$ & $17.6-3.0^{\mathrm{a}}$ & $33.2-2.6^{\mathrm{b}}$ \\
& & & & & \\
Soil temperature & & & & & \\
& $10: 00$ & 5 & $31.4-1.8^{\mathrm{a}}$ & $31.0-1.2^{\mathrm{a}}$ & $27.4-0.7^{\mathrm{b}}$ \\
& $14: 00$ & 0.5 & & & \\
& $14: 00$ & 5 & $34.0-1.0^{\mathrm{a}}$ & $33.8-1.5^{\mathrm{a}}$ & $30.1-0.8^{\mathrm{b}}$ \\
\hline
\end{tabular}

Value denotes average \pm S.D. $(n=6)$.

The different letter denotes the significant difference (Scheffe, $p<0.001$ ).

The measurements were carried out at $14: 00$ on 6 October 2000 .

Soil moisture was presented by volumetric water content estimated by FDR sensor.

\section{B. Seedlings and Saplings Dynamics}

Density of seedlings and saplings was 14.2 per $100 \mathrm{~m}^{2}$ for plot I and 23.2 per $100 \mathrm{~m}^{2}$ for plot II. Number of tree species on the canal bank was 12 in plot I and 25 in plot II. These tree species were a part of trees composing the natural forest next these plots (41 tree species, Tuah et al. 2003). The abundant tree species in the plot I were asam-asam (Ploiarium alternifolium), garunggang (Cratoxylum arborescens) and tumih (Combretocarpus rotundatus) (Table 2). These species are native to peat swamp forests in Central Kalimantan (Tuah et al. 2003), and according to our observation they are usually found on the canal banks around Palangkaraya.

During our two-year investigation in plot $\mathrm{I}$, the following species had newly regenerated: P. alternifolium $\left(\mathrm{n}=41\right.$ individuals $\left./ 500 \mathrm{~m}^{2}\right)$, C. arborescens (11), jambu-jambuan (Sysygium sp.; 1), mahang (Macaranga sp.; 1 ) and (C. rotundatus 2; Table 2). Most of the tree species observed in 2000 survived throughout the two years of the investigation (Table 2). The mortalities of $P$. alternifolium, $C$. arborescens and $C$. rotundatus were 2, 4 and 6 individuals, respectively, over the two years. The high survivorship of seedlings that regenerated in 2001 was also observed in 2002 (Table 2).

The annual height increments of the three most abundant species were $189-232 \mathrm{~cm} \mathrm{y}^{-1}$ (P. alternifolium), 118-289 $\mathrm{cm} \mathrm{y}^{-1}$ (C. arborescens) and $27-255 \mathrm{~cm} \mathrm{y}^{-1}$ (C. rotundatus) (Figure 2). The height increment of $C$. arborescens was the highest among these three species. Relative growth rate (RGR) in tree height was over 100\% when the tree height was less than $1 \mathrm{~m}$, however the RGR decreased with increasing tree height in the three tree species (Figure 2). 


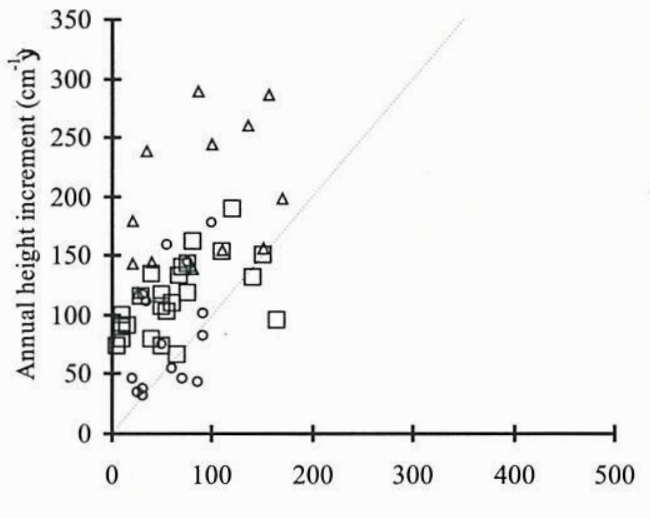

Tree height in October, $2000(\mathrm{~cm})$

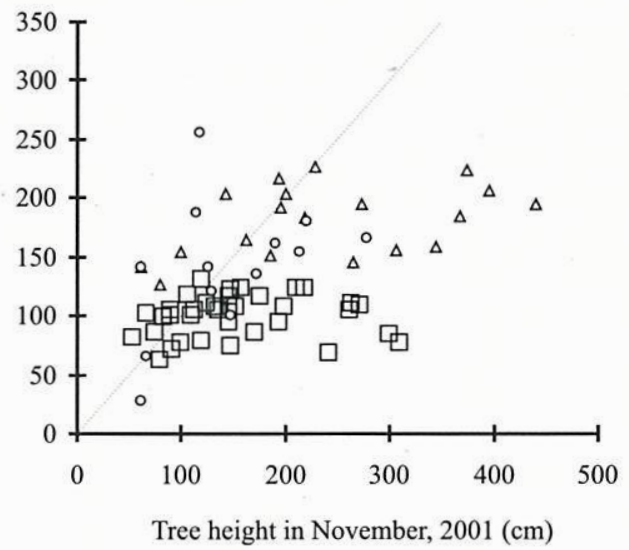

Figure 2. Relationship between tree height and annual height increments. Panels (A) and (B) denote the results from 2000-2001 and from 2001-2002, respectively. Squares, circles, and triangles represent Ploiarium alternifolium (asam-asam), Combretocarpus rotundatus (tumih) and Cratoxylon arborescens (garunggang), respectively. Line denotes $1: 1$ relationship $(R G R=100 \%)$.

The environmental conditions on the canal bank were more intensive radiation, higher soil temperature and greater soil moisture deficit than those on the forest floor in a natural forest (Table 1). In the top of canal bank (plot I), low tree density and smaller number of tree species than those in the second floor (Plot II) were found (Table 2), implying that the top conditions limited the regeneration of tree species. The results showed that there were no significant differences in the soil temperature and soil moisture conditions (Table 1), hôwever greater soil moisture deficit should frequently occur during rainless period in the top of canal bank. In numerous cases, intensive radiation, high temperature and drought conditions inhibit seed germination, survivorship and seedling growth (Kozlowski and Pallardy, 1997, Fenner and Thompson 2005). Here there were three tree species, $P$. alternifolium, C. arborescens and C. rotundatus, which could abundantly regenerate on the top of canal bank (Table 2). Thus it can be evaluated that $P$. alternifolium, $C$. arborescens and $C$. rotundatus have tolerance to intensive radiation, higher soil temperature and greater soil moisture deficit in their regeneration stages.

According to Swaine and Whitmore (1988), tropical tree species may be classified into two distinct groups, pioneer and non-pioneer, based on seed germination and seedling establishment requirements. They suggested that the seeds of pioneer species can germinate only in a sunlit condition such as in canopy gaps, whereas the seeds of non-pioneer species can germinate in canopy shade or in canopy gaps. In higher irradiance conditions, the growth may be strongly inhibited in more shade tolerant non-pioneer (Agyeman et al., 1999). Several experiments indicated that species with a high potential RGR are less tolerant (Fenner and Thompson 2005). The result showed that growth of $P$. alternifolium, C. arborescens and $C$. 
rotundatus was greater than that of Shorea species, in approximately $30 \%$ full sun (photosynthetically active radiation; Turner, 1989; Turner, 1990). This result was also found on those species grown under sunlit conditions in a dry-land plantation (Istomo et al., 1999; Soda, 1997). In addition, according to Shibuya (unpubl. data), the RGR of P. alternifolium, C. arborescens and $C$. rotundatus was greater than that of Shorea species planted in open area in near our study site. Thus $P$. alternifolium, $C$. arborescens and $C$. rotundatus could be fast-growing pioneer species.

Since $P$. alternifolium, $C$. arborescens and $C$. rotundatus are canopy trees in mature peat swamp forests of Central Kalimantan, if these species are planted over large areas, the risk of ecological and genetic disturbance is much lower, as compared to that posed by exotic tree species. On the other hand, the commercial price of $C$. rotundatus timber is much lower than that of dipterocarps. However, $C$. rotundatus timber has traditionally been used by local people for construction of houses. In addition, local people have traditionally used $P$. alternifolium and C. arborescens for fuel, because both are fast-growing species that sprout after logging. The planting of $P$. alternifolium, $C$. arborescens and C. rotundatus may therefore contribute to timber and/or fuel wood production for local people. These three species provide ecological as well as locally economic advantages if they are planted.

The ability of these species to germinate under open and dry conditions provides an additional advantage, making it possible to sow seeds directly on disturbed lands, rather than planting seedlings grown in a nursery. The preparation, transportation, and planting of seedlings for afforestation are laborious and expensive. Also, it is easy to collect seeds of these species, because their seed production begins from young stages and fluctuates little between years. If direct sowing of their seeds is available for afforestation of the disturbed land, the cost of the afforestation could be reduced considerably.

The composition and abundance of regenerated trees on the canal bank depend on the species composition surrounding the natural forest, their seed supply, and germination ability. In this study, the examination is insufficient for the complete classification of the ecological characteristics of many tree species in Central Kalimantan, however, we found such tree species as $P$. alternifolium, $C$. arborescens and $C$. rotundatus that are suitable to preceding planting for afforestation of intensively disturbed peat lands.

\section{CONCLUSION}

The preliminary finding indicated that $P$. alternifolium, C. arborescens and C. rotundatus were tolerant of intensive radiation, soil drought and high soil temperatures during germination. The annual height increments were $189-232 \mathrm{~cm} \mathrm{y}^{-1}$ (P. alternifolium), $118-289 \mathrm{~cm} \mathrm{y}^{-1}(C$. arborescens) and $27-255 \mathrm{~cm} \mathrm{y}^{-1}$ (C. rotundatus); thus, these three species could be classified as fastgrowing with tolerance to open and dry conditions. Such characteristics were important to avoid competition with herbs, ferns, and/or climbers. The results suggest that $P$. alternifolium, C. arborescens and $C$. rotundatus are appropriate for preceding planting for the rehabilitation of the disturbed peat swamp forests of Central Kalimantan. Finally, study on the plantation trial is required to confirm and investigate this preliminary finding. 
Initial screening of fast-growing ..... H. Saito, etc.

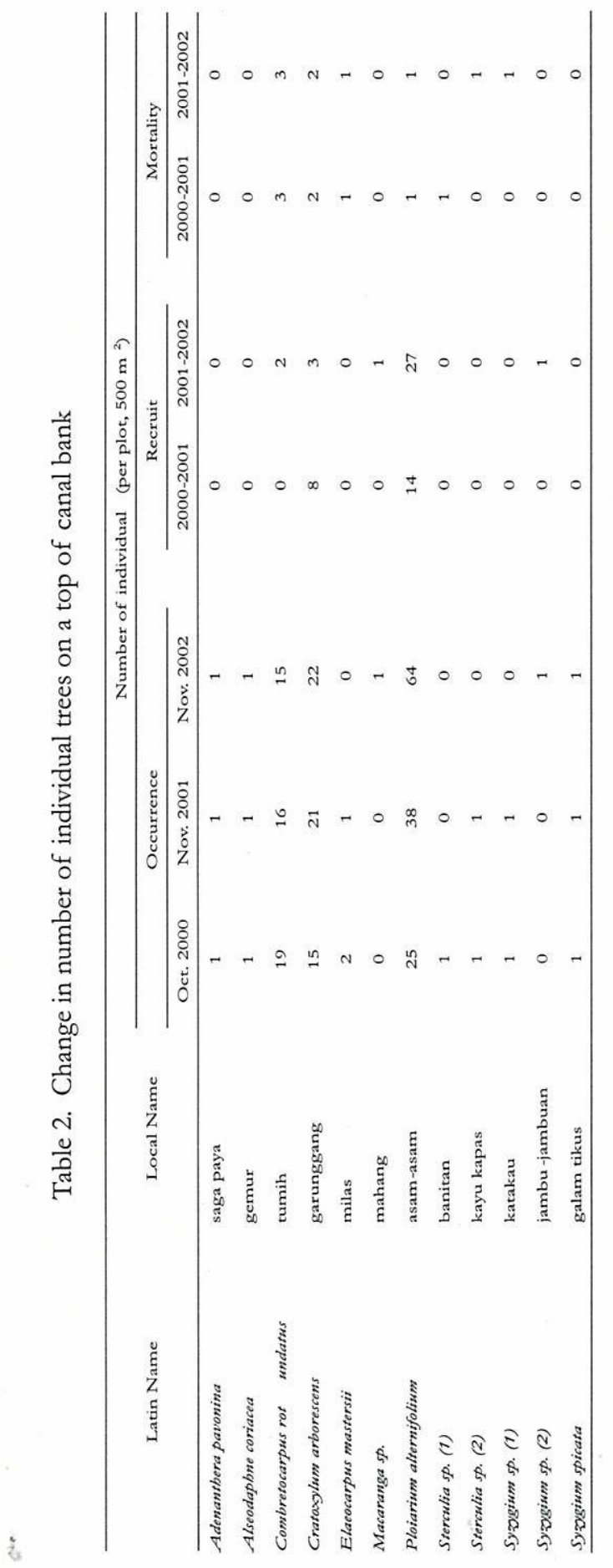




\section{ACKNOWLEDGEMENTS}

We would like to thank Professor Hidenori Takahashi and Professor Mitsuru Osaki from Hokkaido University for organizing this research project. We would also like to thank Dr. Shigeo Kobayashi from Forestry and Forest Products Research Institute for his valuable comments. This study was supported by Core University Program sponsored by the Japan Society for the Promotion of Science.

\section{REFERENCES}

Agyeman, V.K., M.D. Swaine, and J. Thompson. 1999. Responses of tropical forest tree seedlings to irradiance and the derivation of a light response index. J. Ecology 87: 815-827.

Boehm, H.D. V. and F. Siegert. 2001. Land use change and (il)-legal logging in Central Kalimantan, Indonesia. In Rieley, J. O. and S.E. Page (Eds.) Proceedings of the International Symposium on Tropical Peatlands. Peatlands for people: Natural resource functions and sustainable management, pp. 141-149, University of Palangkaraya, Central Kalimantan.

Fenner, M. and K. Thompson. 2005. The ecology of seeds. Cambridge University Press, Cambridge. pp. 250.

Istomo, C. W. and N. Hidayati. 1999. Growth evaluation of Meranti (Shorea spp.) plantations at Haurbentes, BKPH Jasinga KPH Bogor, Perum Perhutani Unit III Jawa Barat. Manajemen Hutan Tropika 5(2):13-22. (Indonesian with English summary)

Jaya, A., J.O. Rieley, T. Artiningsih, Y. Sulistiyanto and Y. Jagau. 2001. Utilization of deep tropical peatland for agriculture in Central Kalimantan, Indonesia. In Rieley, J. O. and S.E. Page (Eds.) Proceedings of the International Symposium on Tropical Peatlands. Peatlands for people: Natural resource functions and sustainable management (pp. 134-140), University of Palangkaraya, Central Kalimantan.

Kira, T. 1977. Forest vegetation of Japan. In Shidei, T. and T. Kira (eds.): Primary productivity of Japanese forests (JIBP Synthesis Vol.16).Productivity of Trees (pp 1-9) Univ. Tokyo Press, Tokyo.

Kobayashi, S. 1988. Peat swamp forest, tropical heath forest, and mixed dipterocarp forest in relation to forestry in Brunei Darussalam. Nettai-Ringyou 11: 17-23 (in Japanese).

Kobayashi, S. 1994. Effects of harvesting impacts and rehabilitation of tropical rain forest. J. Plant Res. 107: 99-106.

Kobayashi, S. 2000. Initial phase of secondary succession in the exploited peat swamp forest (Shorea albida) at Sungai Damit, Belait in Brunei Darussalam. In Iwakuma, T., T. Inoue, T. Kohyama, M. Osaki, H. Simbolon, H. Tachibana, H. Takahashi, N. Tanaka.and K. Yabe (Eds.) Proceedings of the International Symposium on Tropical Peatlands (Pp.205-21). University of Hokkaido, LIPI and IPB.

Kobayashi, S., Y. Ochiai, R. Jillii and R. Wahid. 1996. Preliminary study on composting tropical peat. Bull. For. and For. Prod. Res. Inst. 336: 79-87 (in Japanese). 
Kozlowski, T. T. and S.G. Pallardy. 1997. Seed germination and seedling growth. pp.14-71 In Growth Control in Woody Plants. Academic Press, San Diego, 641 pp.

Sasaki, S. and S. Asakawa. 1994. Silviculture in tropical rainforest zones. Pp. 199-229 In Silviculture. Sasaki, S. (ed.). Kawashima Publishers, Tokyo, 238 pp. (in Japanese).

Soda, R. 1997. Development of nursing techniques for dipterocarp seedlings using ectomycorrhizae. Research Report of reforestation techniques in tropical rainforests, 171195 (in Japanese).

Sugandhy, A. 1997. Conservation and sustainable use of tropical peatland in Indonesia, within the national strategy for environmental management of wetland ecosystems. In Rieley, J. O. and S.E. Page (Eds.) : Biodiversity and Sustainability of Tropical Peatlands (Pp. 23-30), Samara Publishing Limited, West Yorkshire, UK.

Swaine, M. D. and T.C. Whitmore. 1988. On the definition of ecological species groups in tropical rain forests. Vegetation 75:81-86.

Tuah, S.J., Yahya, M. J. and Suwido H. L. 2003. Nutritional characteristics in leaves of plants native to tropical peat swamps and heath forests of Central Kalimantan, Indonesia. Tropics 12: 221-245.

Turner, I. M. 1989. A shading experiment on some tropical rain forest tree seedlings. J. Trop. For. Sci. 1:383-389.

Turner, I. M. 1990. The seedling survivorship and growth of three Shorea species in a Malaysian tropical rain forest. J. Trop. Ecol. 6: 469-478. 